PR

3433

. F28

A6

1909

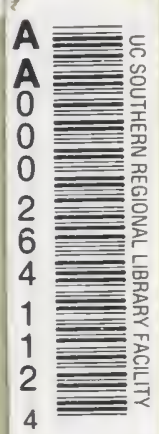

PUBLISHED UNDER THE AUSPICES OF

ifornia

nal

ity
The Poems of Thomas

Third Lord Fairfax

From MS. Fairfax 40

In the Bodleian Library, Oxford

BY

EDWARD BLISS REED

JULY, 1909

LUME 14, PAGES 237-290

$=$

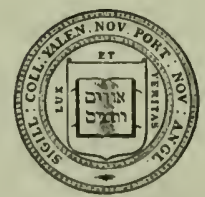

NEW HAVEN, CONNECTICUT 1909 
Digitized by the Internet Archive in 2008 with funding from Microsoft Corporation 
THE UNIVERSITY LIBRARY UNIVERSITY OF CALIFORNIA, SAN DIEGO

LA JOLLA, CALIFORNIA 



\title{
CONNECTICUT ACADEMY OF ARTS AND SCIENCES
}

\section{The Poems of Thomas Third Lord Fairfax}

\author{
From MS. Fairfax 40 \\ In the Bodleian Library, Oxford
}

BY

EDWARI) BLISS REEI)

PUBI.ISHED UNDER THE AUSPICES OF

\section{YALE UNIVERSITY}

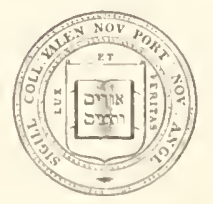

NEW HAVEN, CONNECTICUT 
WEIMAR : PRINTED B: R. WAGNER SOHo 


\section{IV.-- The Poens of Thomas Third Lord Fairfax.}

(From the Bodleian MS. Fairfax 40; formerly MS. Add. A. 120.)

In the annals of England the name of Thomas, third Lord Fairfax, is deservedly illustrious. As a general, he was an intrepid fighter and a skilful commander; in his private life, a man of scholarly tastes, happy in his country estates, which he preferred to the court. Policy and self-advancement were far from his thoughts, despite his great opportunities for aggrandizement; and the simplicity of his character, at which his enemies sneered, was but a proof of his sincerity. To sketch his life in detail is mnecessary, yet his poems will gain significance if, in the briefest manner, we review his interesting career.

The son of Fernandino, second Lord Fairfax, and Nary, daughter of Lord Sheffield, he was born at Denton, Yorkshire, in 1612, of a family long distinguished for its soldierly qualities. In 1600 his grand-father, Thomas, first Lord Fairfax, then a man of sixty, joined, with two of his sons, the single regiment sent by James I to the support of the Elector of the Palatinate. He was obliged to return to England to take part in the Parliamentary elections, but his two sons died at Frankenthal at the head of their trops. Fernandino did not make this campaign, and his father spoke of him as a "tolerable country justice, but a mere coward at fighting" ${ }^{1}$; yet Fernandino took the field agrainst Charles I, and certainly dicl not deserve this taunt.

The early years of our poet were spent in Jorkshirc, and he undoubtedly enjoyed in his first studies the guidance of his great uncle, Edward Fairfax, the translator of Tasso. In 1626 he entered St. John's College, Cambridge, where he remained four years, and then, following the family traditions, he want to the low Countries, to serve under lord Vere against the spaniards. Another young volunteer in the sime camp was Tureme. After witnessing the capture of Bois-le-Duc, he traveled and studied in France for eighteen months, returned to England in 16:32, and repuested permission to volunteer under Gustivus Adolphus, lut his family opposed it, and he retired to the Yorkshire estates to live the life of a country gentle-

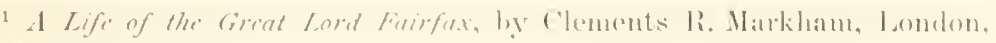
$1870,11.12$ 
man. In 1637 he married the daughter of his commander, Anne Vere, a woman of energy and courage, who followed her husband to the field, shared his dangers (she was once taken prisoner by the Royalists) and, in no small measure, determined his career. ${ }^{1}$

In the two brief and inglorious Scottish compaigns, Fairfax joined the King's army, but when in $16+2$ Charles came to Yorkshire to seize the supplies at Hull, and raise troops against Parliament, the Yorkshire gentry who opposed the King looked to Fairfax for leadership. He was entrusted with a formal protest against the King's actions, and, despite repulses, succeeded in laying this document on the royal saddle at Heyworth Moor, where Charles was endeavoring to win over the gentry of the shire. Fairfax thus showed the world on which side he would be found, and in the Yorkshire campaign that followed, he fought with the greatest courage. Undaunted by defeat, fearing no odds, on at least one occasion he attacked a force that outnumbered his own by four to one. When surrounded, he cut his way through the enemy. At Marston Moor he found himself carried by the tide of battle into the thick of the enemy's ranks. Taking from his hat the white badye worn by the Parliamentary forces, he calmly rode through the ranks of the Royalists, regained his troops, and led another attack. ${ }^{2}$ So fearless was he that on several occasions he narrowly escaped death. In 1644 a musket-ball pierced his shoulder, another broke his arm. Hardly recovered from these wounds, he was again struck at the siege of Pomfret Castle. His skill as a leader, his bravery in action, had attracted the attention of all England, and in 1645, when but thirtythree years of age, he was made Commander-in-chief of the Parliamentary forces, having as his first task the organization of the New Model army. While in the popular opinion it was Cromwell who was "the leading spirit of the war," to quote Sir Clements Markham, the biographer of Fairfax, "it was Fairfax who organized the new army without the smallest assistance from Cromwell. It was Fairfax whose genius won the fight at Naseby, and whose consummate generalship concluded the war, and restored peace. Cromwell was his very efficient general of horse, but nothing more: and indeed he was generally employed on detached duties of secondary importance." 3 At Naseby, Fairfax was conspicuous for his daring; at the surrender of Oxford, he placed a gruard about the

1 Ibid., p. 108.

2 Ibid., p. 171.

3 Jbid., Preface, p. iv. 
Bodleian and saved it from destruction, as he had spared the minster at the siege of York. ${ }^{1}$

With Charles hopelessly defeated, Fairfax was unwilling to depose him, wishing the King to rule, with the constitution safeguarded from encroachments of the crown. He hotly resented the seizure of Charles by Joyce, and through his insistance Charles was allowed to see his friends, and above all, his children--a favor for which he repeatedly thanked Fairfax. ${ }^{2}$ In the political intrigues which preceded the execution of Charles, Fairfax took no part; but when the Royalists made a last stand, he laid siege to Colchester, cap. tured the town, and crushect the insurrection. It was at this time that Milton addressed to him his noble sonnet:

Fairfax, whose name in arms through Europe rings,

Filling each mouth with envy or with praise,

And all her jealous monarchs with amaze,

And rumours loud that daunt remotest kings,

Thy firm, unshaken virtue ever brings

Victory home, though new rebellions raise

Their Hydra heads, and the false North displays

Her broken league to imp their serpent wings.

O yet a nobler task awaits thy hand

(For what can war but endless war still breed?)

Till truth and right from violence be freed,

And public faith clearect from the shameful lorand

Of public fraucl. In vain doth Valour bleed,

While Avarice and Rapine share the land.

Though appointed one of the Commissioners to try the King, Fairfax refused to be present at the trial, and opposed it in vain. Surely there are few more dramatic moments in history than when lady Fairfax rose in the gallery of Westminster Hall to protest against the trial, and to defend her husband's name. Indeed, so well known was laairfax's opposition to the execution of the King that Cromwell accused the general of planning to rescue Charles.

In 1650 Lord Fairfax resigned his command, and returned to his cstates at Nunappleton. On thr death of Cromwell he decided that there would be antrehy unless Charles II returned and ruled. Lambert, with a disciplined amy of ten thousand men, was on the

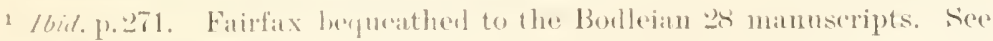

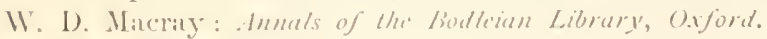

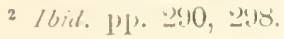


field to oppose Monck, who, with an army of seven thousand, was on the point of declaring for Charles. Though ill and suffering intensely; Fairfax sent word to Monck that he would take the field in support of Charles. When he appeared, Lambert's troops cleserted and flocked to their old commander, and thus, without a shot being fired, the Restoration was accomplished. 1t was fitting that Lord Fairfax should head the commission sent by Parliament to the Hague to invite Charles to return. No honors were conferred on him by the Merry Monarch-he sought none-and he retired to Yorkshire, where he died November 12, 1671, three years before the death of Milton.

It is not surprising that the letters of Fairfax, and his two Short Memorials of the IV ar, should have been published, but it is strange indeed that a manuscript of 656 pages of verse, all in his own handwriting, should never have been carefully examined. This manuscript passed from the possession of the Fairfax family, and was owned successively by Ralph Thoresby; the Duke of Sussex, and Dr. Bliss of Oxforct, from whose collection the Bodleian library, its present owner, purchased it in 1858. Archbishop Cotton, in his Editions of the Bible and Parts thereof in English from the year MDI to MDCCCL, Preface to the second edition, 1852, gave a table of contents of the manuscript, then in the possession of Dr. Bliss, and reprinted one of the paraphrases of the Psalms. Sir Clements Markham, in his Life of Fairfax, already cited, went further; for in the text of his work he reprinted three of Fairfax's poems, ${ }^{1}$ and in an appendix gave ten more, wholly or in part, but as a historian, interested in the political, and not the literary life of the times, he made no study of the manuscript. Since Narkham, 1 can not find that any one has examined these poems or published them.

We have no means of dating the poems, with the exception of the following:

Upon the New-built House at Apleton (1650), To the Lady Cary upon her IVerses on my deare IV ife (1665), On the Fatal Day (1649), Upon the Horse which his Majestie Rode upon att his Coromation

1 Life of Fuirfax, p. 352: On the Fatal Day, Jan. 30, 16.78; p. 365, Upon the Veat-built llonse at Aplcton: 1).381, Upon the Horse which his Majestie Rode upon Att his Coronation. Appendix A, pp. $415-127$ contains the following: Preface to the Psalms, llonny dropps (excerpts), The Solitude, The (hristiun llarfare (exerpts), Life and Death Compared together, Shortness of Lifc, of Beauty, Upon a Patch Face, Upon an ill Ilusband, and two of the liutgar Proverbs. 
$(1660){ }^{1}$ As these poems are written down in this order, it will be seen that their position gives no clue to the time of their composition, indeed, the very last poem in the manuscript is an eclogue, Hermes and Lycaon, by Edward Fairfax, who died in $1635 .^{2}$ If we refer Fairfax's translations from "good old Mantuan" to his student days, the poems certainly cover a period of forty years.

A perusal of the manuscript shows us at once that Fairfax is not a poet, but rather a man of poetic tastes, an admirer of verse. We have, then, no discovery of a neglected genius, and there will be no call for the Complete Works of Thomas Fairfax. It will occasion no surprise, therefore, that we have omitted a consiclerable amount of his poetry. ${ }^{3}$ It will readily be seen that the chief defect in these poems is their poor technique. Fairfax had very little sense of rhythm; at times his ear seems absolutely untrained, and, though a multitude of corrections in the manuscript show how hard he struggled to improve his lines, yet his revisions are grenerally as awliward as his first rude draft. Few of his poems have any metrical charm, and when in his Honey Drops or I Iulgar Prouerbs he seeks to become epigrammatical, he lacks both point and finish. His best writing is seen in such a poem as David's Lamentation, or in the straightforward couplets of the Christian IVarfare; however, it is not for his skill as a writer that Fairfax deserves attention, but for certain conclusions that may be drawn from the subject-matter of his lines.

Fairfax divided his poetry into religious and secular verse, the former occupying 551 pages out of 650,388 of these being devoted to a metrical paraphrase of the Psalms. From the days of Wyatt and surrey in England and Clement Marot in France, to "translate" the Psalns, or incleed to turn any part of the seriptures into verse, was a pastime indulged in alike by the clevout and by the proflixate. A complete list of English writers who from 1500 to 1700 made metrical versions of any portion of the Bible has never been compiled. It would be a surprisingly large one, and, thongh Farfax was a devout man, he was following a literary fashion as well as his own inclination in his paraphrase which offers so little that is

1 The Epituph on 2. I: diring binnge night he ditted. were we sure that V. stands for Vere.

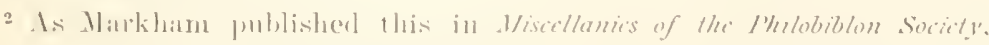

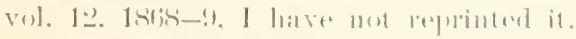

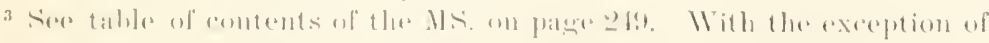

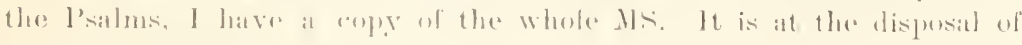
any one intriested in it. 
interesting that I have reprinted but four Psalms, enough to show his method. ${ }^{1}$ In his hymns we notice most of all that he writes in an impersonal style, for we have in them no picture of his own mind, no account of his spiritual conflicts, his doubts, his defeats, or his victories. Religious verse is valuable in proportion as it shows us the soul of a man, and this is precisely what Fairfax cloes not attempt to do.

This same lack of the personal element in his writing is a marked defect of the secular verse also, for he gives us practically nothing of his own life, even in remote allusion. When we consider the wreat scenes he had witnessed, the part he had played in shaping the destinies of England, it is rather surprising that he should choose to write on Enzy, Temperance, Anger. Surely he might have written with more spirit on Liberty, Tyranny, or Valor. He collects many popular proverbs, but he does not jot down the song of his soldiers. For a fighting man, how faint and unrealistic are such lines:

As men besieged with mines about Ready to spring and ruing [sic] all, Hearing the alarm beat, runne out To th' assault and gard ther wall, And by the blast in ruins sinke Vanquist are when they least thinke. ${ }^{2}$

And yet they are quite unusual, so rarely does he refer to the shock of battle. As Fairfax does not tell us what he has felt, so he has little desire to write down what he has seen. Apart from all considerations of the immeasurable distance that separates Andrew Marvell's work from that of Fairfax, it is yet surprising that Marvell should describe Appleton House and the estates so fully, and that Fairfax, who delighted in them, should give us but a few faint lines on the new-built house. Similarly we should expect the sympathetic picture of the last moments of Charles to

1 Markham, in his Life of Fairfux, p. 369, mentions another copy of Fairfax's version of the Psalms, owned by Mr. Cartwright of Aynho. I have not attempted to trace this. At the end of the MS. of the Short Memorial, at Leeds Castle, are versions of the 18th, 24th, 30th, and Sith Psalms. He prefaces Psalm 18 with the following: "That I chuse this 18 Psalm let none think that I arrogate anything to myself, for farre be it from me to applie it otherwise than as David's triumph over his enemies: 'See Markham's Fairfax, p. 415.

${ }^{2}$ A IIymne to Christ the Messiah. 
come from the pen of the general rather than from the tutor of his daughter. ${ }^{1}$

To observe for one's self, to describe one's feelings, demands a certain amount of originality, and this is precisely what Fairfax lacked. The greater part of his religious verse was paraphrase, and we naturally look for translation in his secular poems. Pages 602-10 of the manuscript are taken, he tells us, from the French, the Italian, the Latin. With the exception of the Mazarinades, all these translations are directed against Rome, showing his strong Puritan sympathies. It is interesting to notice that when he translates Petrarch he does not choose the somnets to Laura, but The Character of the Romish Church. ${ }^{2}$ Petrarchism, brought in by Wyatt and Surrey a century before, had spent its force, and the lyrics of Philip Ayres, 1687, fill the last book that shows the old sway of the founder of the modern lyric. ${ }^{3}$ As confirmation of Fairfax's lack of skill in writing, it is noticeable that he is unable to reproduce the sonnet form, and turns the quatorzains into poems of twelve lines.

Eight pages of translation, however, constitute but a small part of his secular verse. As we read it, we are impressed by the contrasts it shows, contrasts that can not be explained by assuming that certain poems are separated by long intervals of time. Lady Carey had written to Fairfax a metrical epistle on the death of his wife, and he felt called upon to answer it. Knowing his devotion to Lady Fairfax, we expect him to rise above himself under the inspiration of his grief, lout his thought is so trivial, and so feebly expressed, that To the Lady Cary Upon her lierses on my deare IVife is one of the poorest poems. A few lines will show this more plainly than any comment:

Natdam

Could I a Tribute of my thanks express

As you have done in love and purer verse,

On my best selfe then I might Justly ratise

Your Elogry t' Encomiums of your Prayse

And soe forgett the Subject that diel move

Ne to at thankfulness as 't dicl you to love.

O twere to great a Crime but pray allow

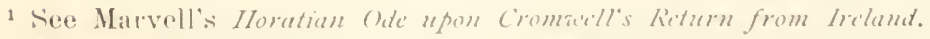

2 Somnets, De lario Argumento, Nos. 11 and 16.

${ }^{3}$ Lyric I'o'ms, mate in Imitation of the' Itulians, London, 1687.
} 
Wher I fall short but you have reached to, Making that Good wisest of Kings hath said,

Th' Living's not soe Prayse-worthy then $[$ sic $]$ the dead.

A few pages further on, we come to a more formal elegy on Henry of Navarre.

Ah is itt then Great Henry soe fam'd

For taming men, himself by death is tam'd!

Whatt eye his glory saw, now his sad doome,

But must desolve in Teares, sigh out his Soule,

Soe small a shred of Earth should him intombe

W'hos acts deserv'd pocession of the whole.

Though this poem has its defects, it is, on the whole, a better piece of writing than the elegy on Lady Fairfax. This consideration, together with the fact that Henry of Navarre was assassinated two years before Fairfax was born, and that there seems to be no special reason why he should lament his death, makes one suspect that the lines are a translation from the French. Such is the case, for I find that the poem is taken word for word from an elegy by Anme de Rohan which Fairfax read at the end of Agripla d'Aubigne's Histoire Universelle, published 1626, for d'Aubigné does not quote the whole poem, and Fairfax translates only as much as he gives. ${ }^{1}$ With this hint I have looked in the French literature of the period for the originals of the other poems. On a Fonntain is a translation of an epigram of Malherbe that was a favorite one, ${ }^{2}$ to judge from its appearance in a French anthology (Les Délices de la Poćsie Française, 1615), while Fairfax's best poem, the one that gives the manuscript its title, is a translation of Saint-Amant's La Solitude. Other sources I have not found, but I feel convinced that many of the poems are translations, as for example, Of a Faire $W$ 'ife, to Corgio, which is probably taken from the Italian. Others better read in Continental literature of the period may discover his models. ${ }^{3}$

We are now in a position to see the significance of these poems. They are not fine examples of English verse; they are rather to be regarded as documents that show us what an English gentleman

\footnotetext{
1 Histoire Unizersolle par Agrippa d'Aubigné (Paris, 187!), Vol. !', pp. $472-75$

2 See Oentres complètes de Malherbe (Paris, 1862), Vol. 1, 1) 205.

3 Mr. Lewis C. Everart, Yale Phi Beta Kappa Fellow 1908-1909, has searched in the Bibliothèque Nationale, Paris, for other French originals, but without results.
} 
of the Caroline and Commonwealth period read and thought. They are like an old diary in which a great man has jotted down a list of the books he owns, or of poems he has memorized; they are like a package of old letters, in which the writer tells us of his favorite authors and his literary tastes. It is to be observed that this moralist, who mentions but one English writer-his great-uncleturns to French literature. La Solitude is certainly not only SaintAmant's best piece of work, but one of the finest French poems of the period, and the evident admiration of Fairfax for it speaks well for his taste. Though Saint-Amant had twice visited London and was possibly known there as a poet, only two other unimportant translations of his verse have been noticed in English literature. ${ }^{1}$ It is worthy of mention that Saint-Amant himself had some very pronounced opinions concerning Fairfax, who probably never read the Frenchman's Epigramme Endiablie sur Fairfax. ${ }^{2}$

There is another interesting point concerning La Solitude. It is well known that in 1650 Andrew Marvell came to Appleton House as a tutor for Nary Fairfax. He had already written verse, but it had not been nature-poetry; his grotesque Flecnoe and his absurd verses Upon the Death of Lord Hastings have nothing of the meadow

1 See A. H. Upham, The French Influence in English Literature from the Accession of Elizabeth to the Restoration. New York, 1908, 19. 345. 10\%, 409. 112 It is interesting to read Saint-Anant's brief reference to Ben Jonson in his L'Albion.

2 Je erois quil doit bien estre en peine,

liexecrable tran qui presibe aux enfers.

Quand. daus les feux et daus les fers,

Il songe au noir objeret des formles de ma liaine:

Son viens soretre enfumí tremble en sa tiere main:

Il redonte Fairlax, ce prodige inhumain:

1] craint que ce monstre unaspire

An degre le plus haut de son horrible mpire,

le degré le phus haut est reluy le plus bas,

Cerst on re mince des sabats,

Des entroits les plus dairs anx endroits les plus sombres,

Tomba pour regner sur les (mubres:

("est lal, dis-je, gu'il raint que yall quelque attentat,

bue par quelque nuogen olulique.

Fiblitx naille du moins reurerser som estat

Pour ent filje more rejubligure.

lit voila les masous qui l'ont l'ait hesiter

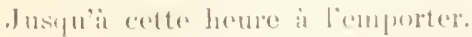

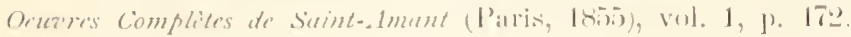


in them. During the two years he spent at the home of Fairfax, Marvell wrote those nature-poems that determined his fame-Upon the Hill and Groze at Billborow, Upon Appleton House, On a Drop of Dew', The Garden-poems that show an observation, an apprecation of the earth, of flowers, birds and trees unsurpassed in all the works of his predecessors in English poetry, not excepting the very greatest, Chaucer, Spenser, and Shakespeare. That these poems were inspired not only by the beauty of Nunappleton, but by its owner's love and appreciation of poetry, there can be little doubt. IT'e may go even further, and see in Marvell's nature-poems some hints from Saint. Amant. Marvell's verse is richer and deeper; where Saint-Amant is vague in his descriptions or conventional in his thought, Marvell is concrete and original; for it is the Englishman, and not the Frenchman, who uses le mot precis, and yet SaintAmant's theme-to lose one's self in Nature-is the theme of The Garden and of the finest lines in Appleton Housc.

We see now the significance of the poems of Fairfax. They throw light on the character of a great Englishman; they remind us that the literary influence of la ville lumiere was still powerful in England, that it had not died with the sonneteers; and they give us the atmosphere in which Andrew Marvell lived and wrote the tenderest, the sincerest, the cleepest nature-poetry of the seventeenth century.

Yale College, Edward Buss Reed.

February 19, 1909. 
TABLE OF CONTENTS OF MS. FAIRFAX 40.

The poems marked + are reprinted here. Those marked $\because$ are given only in part. The poems are printed as they stand in the MS. with no changes in the punctuation or spelling. 
[Title] The Implomient of mi Solitune. T. F. p. i.

$\uparrow$ The Preface to the Psalmes. p. ii.

* Psalms 1 to 150 , in verse. pp. 1-388. [p. 389 is blank.]

Songs of the Old and New Testament. pp. 390-479.

* Moses Songe. Exodus 15. p. 390.

Moses Songe. Deut. 32. p. 396.

The Songe of Deborah. Judges 5. p. 406.

Hannah's Songe. 1 Sam. 2. p. 415.

$\dagger$ Dauids Lamentation for Saule \& Jonathan. 2 Sam. 1. p. 418.

$\dagger \quad$ Hezekiah's Songe. Isaiah 38. p. 422.

The Songe of Mary the Blessed Virgin. Luke 1. p. 427.

Zachariah's Songe. Luke 1. p. 429.

$\dagger \quad$ Simeon's Songe. p. 431.

* The Songe of Salomon. Chapter 1. p. 432. Chapt 2. p. 435.

Chapt 3. p. 438. Chapt 4. p. 440. Chapt 5. p. 444.

Chapt 6. p. 448. Chapt 7. p. 451. Chapt 8. p. 454.

Out of the Prouerbs of Salomon. p. 458.

Wisdom's Antiquity. pp. 471-475.

Out of the Prouerbs of Salomon. p. $473^{\mathrm{b}} 473^{\mathrm{c}}$.

[These two pages were formerly pasted together. They are a repetition of $\mathrm{pp} .458$ and 459 . with two lines of 460 .]

Samuel's Instruction from his Mother. Proterbs 32. p. 476. * Honny dropps. p. 480.

Hymnes to the Soueraine God. p. 510.

A Hymne to Christ the Mesiah. p. 519.

A Hymne to the Holy Ghost. p. 539.

$\dagger$ A Songe of Prayse. p. $549-551^{\text {a }}$.

[Title] The Recreations of my Solitude T. F. p. 551 .

$\uparrow$ The Solitude. p. 552.

$\dagger$ Of a Faire Wife to Coregio. p. 564.

$\uparrow$ Of Beauty. p. 568.

$\uparrow$ Upon a Patch Face. p. 570.

Upon a Younge Virago. p. 571.

$\uparrow$ Upon an ill Husband. p. 571.

$\dagger$ Of Envy. p. 572 .

$\uparrow$ Of Anger. p. 574.

$\dagger$ Of Virtue. p. 577.

Of Patience and Temperance. p. 579. 
$\dagger$ Nature and Fortune. p. 582.

$\dagger$ The Christian Warfare. p. 583.

$\uparrow$ Life and Death compared together. p. 590.

$\dagger$ Upon a Fountaine. p. 592.

$\dagger$ Upon the New-built House at Apleton. p. 593.

$\uparrow$ Shortness of Life. p. 594.

$†$ Epitaph on A. V. dieng Younge. p. 595.

† The Lady Caryes Elogy on my deare Wife. p. 596.

$\uparrow$ To the Lady Cary Lpon her Verses on my deare Wife. p. 598.

$†$ On the Fatal Day, Jan. 30th, 1648. p. 600.

$\dagger$ Of Impartial Fate. 1). 601.

Epitaph sur le Mort du Cardinal Mazarin. Epiodium. p. 602.

† A Carracter of the Romish Church by Francisco Petrarca, Laura Can. 106. p. 604.

Pontanus writes this Epitaph on Lucretia daughter of Alexander 6. p. 606.

Baptista Mantua reproving the wicked Life of Sixtus 4 maketh the Divel give him this Entertainement in Hell. D. 607.

Mantua Eclogae 5. p. 608.

Palengenus A Papist thus discribes the monstrous Corruptions of the Romaine Clargie. p. 609.

Upon Mr. Stanley's Booke of Philusophers supposing itt the Worke of his Tutor W. Fa. p. 611.

† Upon the Horse $w^{\text {ch }}$ his Matie. Rode upon att his Coronation 1660. p. 612.

* Vulgar Proverbs. p. 613.

$\rightarrow$ The teares of France for the deplorable death of Henry 4 surnamed the Great. p. 641.

An Esrloge maide by my uncle Mr. Ed. Fairfax in a Dialogre betwixt two Sheapards Hermes and Lycaon. p. 647. 
[p. ii] The Preface to the Psalmes.

Vaine Fancy whether now darst thou aspire $W^{\text {th }}$ smoky Coales to light the holy Fire Could thou indeed as $\mathrm{w}^{\text {th }}$ the Phenix burne In perfum'd flames \& into Ashes turne Thou might'st hope (vaine hope) yet once againe To rise $w^{\text {th }}$ purer notions in thy Braine But t'would nott serue for they would still be darke Till from thyn Alter Lord I take a sparke

I need not then assend up any higher In offring this to fetch another fire Inspired thus may on my Muse distill Dewes nott from Parnass but Herman's sweet Hill.

[p. 1]

\section{Psal 1}

Blest is the man in walking daly shuns Pernitious Councel that from th' wicked Comes Nor to the sinners paths his steps doth bend Or he yitt up to Scorners chaire assend Who in the early morne \& euening laite On lawes deuine makes choyse to meditate As by the runing streames the well sett tree His fruit in season yeild, the iust shall be Whos leafe shall neuer fade \& what he doth Shall thriue as itt \& shal be fruitfull both But $w^{\text {th }}$ the wicked itt is diffrent farre As chaff tost in the Ayre, So they are Nor shall he stand fore th' impartial Judge Or mongst the iust who in sins way doe trudge

The heauens Lord the siluer studed frame They are the Curious works thy hands declare Time vnto time itt doth recount the same To places most remote, ther voyce it heares Ore all the earth ther arched Sphers extends The Tun on's throne ther rises ther desends 
As cherfull brid-grome in his nuptial state Or actiue men to race $w^{\text {th }}$ ioy Come out From East to West so rms he at that raite Till his cirquitt rownd he'as gone about All parts euen to thé wide Earths extreames Both light \& heat takes from his radent beames

[p. 39] Thy law ô Lord to soules perfection giues They that are simple by thy words made wise They shall reioyce who in thy precepts liues Thy Statutes pure inlighten's the blind eyes To feare the Lord will is preserue for ener Whos iudgments true \& rightious altogether

More sweete then honny yea or gold refin'd Thy seruants setts them att a hier prise They great rewards in keeping them do find But $\hat{o}$ alas who ist his errors spies My faults vnseene $\hat{o}$ let ther none remaine From bold-fac'd sins thy seruant Lord restraie

[p. 40] O let not sin $w^{\text {th }}$ it's tyranick might Ere gitt a iuri[s]diction oner mee

So in my soule shall I then be vpright And from the great transgression guiltless be So shall my words \& thoughts acceptance find IV th thee my strength redeemer of man-kind

How can I want the Lord my sheapard seemes Who to the verdant pasturs leads me outt By Howry bankes wher waters gently streams My soule he doth refresh he sets my foot In paths of truth \& eacual Justice both This only for his owne name sake he doth

Al Though I through death[s] shady vale doe wroe

No terrors ther shal makes me yitt affraicl

His rods my gruicle his staff my strength also

Before myn foes my talble he doth spread

$\mathrm{IV}^{\text {th }}$ oyle my head lull cups my hart doth chere

Him in his house for ener I'le serue ther 
If in distress ${ }^{\hat{}}$ Lord thou 'It gine me ayde

What need I feare though rocks in seas be throwe

Though by ther rage the hills on hills be layd

Thou still preseruest thos that are thyn owne

In thes o're tumings shal noe fear cease them

For God was ther, his help in season Came

When furious rage procest the Heathen world

Thou was to vs as a strong Towre in War

Thou spake the word \& Earth on heaps was hurld

Come se then ther what great vastations are

[p. 105] T'is he when wars arise Can stop ther Course

This he ther weapons breake ther Chariots fire

Wait thou on him know he's a God of force

Did he not rule the world $t^{\prime}$ would soone expire

He mongst the Heathens will exalted be

But Jacobs Gods the Towre to whom we flee

[p. 390]

Songs of the Old \& New

Testiment

Moses Songe

Exodus 15

Vnto the Lord let prayse be sung

Who gloriously triumphed hath

For he into the sea hath flung

Both Horse \& Rider in his wrath

The Lord my strength \& songe shall be

Who my sure saluation

Nine \& my father's god is he

Soule be his habitation

[p. 391] A man of Warr's the Lord renown'd

His name is by Jehouah knowne

Who in the Sea hath Pliaroah drownd

Downe Captains Horse \& Chariots throwne

This goodly Traine $w^{\text {th }}$ fury drunke

The waues as Conerings did Containe 
Wher to the bottome they are sunke

As stones that neuer rise againe

Thy hand o Lord has done this deed

Glorious in Powre art thou become

Thy hand 1 say when ther was need

'Th' insulting Foe has ouercome

[p. 392] They that agaist thee did Combine

Thy wrath has broke in thy defence

As stuble th'are before the winde

So powrefull is thyn' excelence

Thy Nosthrills w $^{\text {th }}$ a blast haue layde

The liquid Seas on sollid heapes

The floating waues ther $w^{\text {th }}$ were stay'd

As Ice Congealed in the depths

Pursue o'retake th' enimy said

Ther spoyles let vs mongst is deuide

Whilst $w^{\text {th }}$ ther Swords they hauack macle

And lust as law to them was gruide

[1. 393] But in a happy howre thou did

The Treasures of thy winde display

So sunk they as the heauy lead

And vnder watry-Monntains lay

Amongst the Gods who's like to thee

O Lord in Holiness \& Prayse

The fearfull wonders $w^{\text {ch }}$ we see

Doe Trophyes to thy Glory raise

Thou stretcht thy hand \& they were gone

The gapinge earth denourd them guite

To th' Holy mountaine thon lechlst on

The chosen Flock of thy delight

[1. 394] Nations hard this $w^{\text {th }}$ pale-fac'il luoks

And horred feare amazed stord

Edom Moab \& syrian I)ukes

Ditt melt away wth Canan's broode

Thy Glorious Name dicl soe apall

Ther trimbling Harts $w^{\text {th }}$ feare $d$ illead

That as a stone lie still they shatl

Till those pass oner thru dost lead 
To Zions mount thou didst them bring Didst plant them in its firtil soyle The place wher thou delightst in

A sanctuary freed from toyle

[p. 395] Raigne Lord for euer v1l-opposd

For Pharoa's Horse \& Men are drownd

Him \& his force hath sea inclosd

Whilst Israel marches on dry grownd

Miriam the Prophetiss a Timbrel takes

Wher in their Circulinge-dances round

The Virgin-Traine such Musick makes

As th: Hills about $w^{\text {th }}$ Ecchoes sound

Then Miriam answered them \& sunge

The Lord triumphd in Glory hath

Proud Pharoah into th' sea has flunge

IV th Horse \& Rider in his wrath

[p. 418] Dauids Lamentation for Saule \& Jonathan.

2 Sam : 1

Israel has lost her ornement

Alas for itt lement

How are her Mighty, falne \& laine

\& on Mount Gibea slaine

Ô let itt nott in Gath be knowne

Or told in streets of Askelon

$\mathrm{O}$ lett nott Lord our ancient Foes

Joying Deride our woes

Least daughter of th' vncircomcis'd

Triumph o're vs dispis'd

[p. 419] Noe more lett fruitfull showres distill

Or dewes on Gibeas direfull Hill

Nor e'er may any thither bringe

More a Heaue-Offringe

Ther th' Mighty fell, Saule lost his sheild

In this shamfull feild

On him regardless they did treade

As if noe oyle had touch'd his head 
Sharp Arrowes shott from Jonathans Bow

Drunk $w^{\text {th }}$ the blood of Foe

Nor did Sauls sword rebate a Jott

Till he'ad his ${ }^{1}$ enimys smote

[p. 420] How louely-pleasant are you tow

Death Could not lone disjoyne in you

Swifter then Eagles $w^{\text {ch }}$ th' Ayre peirce

Both stronge as lions feirce

Israel's daughters lement the fall

Of your valiant Saule

Who you in Purple \& Scarlet deckt

And did from Foes your land protect

How pleasant was itt to behold

Your orniments of Gold

Thy worthys by the sword, how are

They thus cutt off in war

[1. 421] O Jonathan my harts delight

Slaine in the bloody fight

Mount Giboa saw the woefull day

Thou mongst her Rockes ther wounded lay

How can I Deare Jonathan express

For thee my sad distress

Noe Woman's loue reach'd thatt degree

As thou once loned mee

How is the Mighty falne, is Crusht

And Israels Worthys rould in dust

[1. 422]

Hezekialns-Songe

lsaiale:38

In Cuttinge off my days 1 said

Must I goe downe to deaths cold shade

Youth's flowre noe sooner Budd but Blast

be Cropt and to obliuion cast

Mongst lining Lord must 1 noe more

Lift vp myn eyes \& thee adore

"Fablax has written over this line "his foes had smote." 
Or longer in this vniuerse

$W^{\text {th }}$ Man-kind hane noe more Conterse

Farwell then Suns chearful light

Whose Rayes expells the shades of Night

[1. 4.23] Adein deare silner-Horned Moone

By step \& step our time setts downe

Yee Stars farwel that in Night appears

Runing in your apoynted Spheres

Who from your orbs soe far from hence

Throwes downe on vs your influence

Stay when you will your Constant Course

For oner death you haue noe force

Farwel my Friends, farwel delight

Denided by Eternal Night

My flitting years how soon th'are spent

Remoned as a Sythian Tent

Here to day to morrow dead

[p. 424] Cut off like to a weaners thread

In morning when new hopes began

Er' euening pimning sickness came

Yitt did'st nott heare my sad groanes

But lyon-like brake all my bones

$\mathrm{O}$ whatt a little space is this

T'wixt Being \& not Beinge is

Euen from th' Eueninge to the Day

My wasting Sperits faide away

As Crane or Swallow sett alone

To the ô Lord I make my mo'ne

And as the Done that trembling sitts

When Hawke aboue doth sores his pitch

[p. 425] So faints my hart so failes myn eyes

In seing such sad miseryes

But thou in Mercy hast noe piere

O help me in this troubled feare

What shall I say but sure thus much

Thy Word \& Truth keep perfait touch

For sin my soule shall all itts days

Walke softly in my pensiue wayes

By these things Lord doe Mortals line

New life by these things thou dost gine

Lo, Peace to me dost thon restore

And Joy for Greefe I had before 
Thou pluckt me from destrctions Pitt

[p. 426] And all my sins didst thou remitt

For who in death can offrings bringe

Or in the Grane thy Prayses singe

Of All to Shades beneath repare

Does any hope for Mercy ther

The liuinge tis the liuinge They

Shall Prayse thee as I doe this day

Father to somme relate shall this

How faithfull are thy Promises

Since Lord thou hast prolong'd my days

On Warbling Harpe l'le giue thee prayse

And in thy Courts $w^{\text {th }}$ Holy Fire

Ot Zeale pay thanks till I expire

[1. 431] Simeon's Songe

As thou hast said soe Lord pray I

In peace now lett thy seruant die

sence my blest eyes haue seene ith end

Saluation from thy Throne clesend

Which thou before earth frame was layd

To sane Man-kind decrued had

A light to guide the Gentiles ways

Of Israel's sones to be the prayse

[p. $433 \overline{5}]$

[The Songe of Salomon]

Chap :

I am the Rose of Sharon's fruitfull feild

The Lilly $w^{\text {ch }}$ the humble vallyes yeild

In midst of thornes as Lilly appear's abouc

soe mongst the youthfull Virgins is my loue

As Apple-trees 'mongst trees o'th Forrest growe

Anomest the soncs of Men my loue is soe

Vinder whose shade is my delightfull seat

And to my tast his finit is pleasint meat

Then to the house of wines he bronght me in

Wher lone like hamners was a Couer in

stay me $w^{\text {th }}$ flarerens $w^{\text {th }}$ Apples Comfort giue

Who's sick of lone may yitt hate hope to liue 
I'nder my head his left hand stretched out And $w^{\text {th }}$ his Right $h^{\prime}$ imbraceth me about [1. 436] O Zions danghters I strictly you adiure By the swift Hynde \& fearfull Roe be sure Noe stir by noyse you make for to disease Or wake my loue before the time he please Behold I hear his Voyce o're Hills \& Downes My loue Comes skiping ouer Mounts \& bounds Like th' Hart or nimble Fawne \& triping Roe Standing behind our Wall Behold him Loe Through trelest windows how he looketh out His Church $w^{\text {th }}$ watchfull care he vews about Thus speaking to me I my loue did heare Arise my faire one Come away my deare Lo winters past $w^{\text {th }}$ her stormy showers Th' Earth now shew's her various coulred flowrs Chirping of birds a signe the spring grows near

[p. 437] We in the land the mourning Turtle heare The Figg-tree budding green her Figgs disclose The tender Grapes of Vines smell as the Rose Arise my faire one Come away my loue Whom Cliffy Rocks doe hid Come out my Doue Shew me thy Face myn eares let thy Voyce meet Thy Countinance is Comely, Voyce most Sweet Take th' Fox \& little Foxes in thy Toyles That thus our tender grapes \& Vinyard spoyles My deare is myne \& I am his who 'monge The Lillyes feed till shades of Night be gone Turne my beloued turne like th' Roe that trips Or nimble Hinde that in Mount Bether skips.

[p. 480] Honny clroppss.

(Under this title Fairfax has written one hundred and twenty five couplets and thirty tive quatrains)

Why good men haite all sin 'tis understood Because tis both gainst god and ther owne good To walke $w^{\text {th }}$ god tis goodmen's care we see But leaves the Care to god $w^{\text {ch }}$ way 't should be 
Noe safty $w^{\text {th }}$ out god in Freindship were Yitt safe $w^{\text {th }}$ enimyes if God be there

[p. 482] A good man questionless was never hee Thatt strives nott allways better for to be

[p. 183] Good Conscience is a name att $\mathrm{w}^{\mathrm{ch}}$ Men tante But betters a good name then Conscience want

[p. 484] Whatt before men we are affrayd to doe Fore God to thinke itt should affright us too

Nany the Sacred ordinances use Making noe proffet of them-them abuse

[p. 186] When thou clost well or any good thou can Prayse nott thy worke, the worke will prayse the Man

[p. 487] The soule by such a Noble sperit moves Tis nott soe much where't lives as wher it loves Sure best are they, nott they who most can talke How Good God is, but who most with him walke

[p. 490] In sweetest Natures this will sure befall None All can like nor shall be lik't of all

[p. 491] All Earthly things are such as ther's noe (loubt Worst Men may have and best may goe $w^{\text {th }}$ outt Yett wanting them a man may happy be When others w $^{\text {th }}$ them have butt misery

[p. 492] Noe Time in pastime need we Idly wast For time will pass from us in too much hast

[p. 507] I'th' Sacred Arke Reason of State should lye But rules of state should nott Religion tye

When men $w^{\text {th }}$ wine themselves like beasts abuse Not wine the Men but the wine misuse

[p. 509] In all thou undertskes be carful still That none of thee can speake deserved ill And soe when that is done thon needs not Care For 111 men's Censure (Tis the Common fire) 
A Songe of Prayse

Earth prayse the Lord him Reverence beare As well for's Thunders that we heare

At $\mathrm{w}^{\mathrm{ch}}$ poore Mortals stand affraid

As four the glotious Maruels which

Such splendors doth the world inrich

They are the workes his hands hath made

His Prouidential loue lets singe

That $w^{\text {th }}$ a plentious flowinge springe

Our barren soules hee watered

The East the West tast of his Care

Hott Affrick nor the freezinge Beare

From his al seeinge eye is hidd

[p. 550] And wast nott he $\mathrm{He}$ who did please

$W^{\text {th }}$ semeral kinds to store the Seas

Of Fish beyond account Nay more

Made IVoods \& Hills that Cataile yeilds

Gaue flowry Pasturs verdent feilds

That bringe both Corne \& wine great store

But how doe we his mercy wronge

He sees wee still in Sin grow stronge

And day by day his patience moue

Yet as a Father ready is

To pardon faults he sees in his

Such are the tokens of his loue

[p. 551a] In vs Affections ôh tis strange

Wth our light humor suddaine Change

As in a moment they grew old

They $w^{\text {th }}$ the Wind are easely driuen

But his is alweyes firme \& eut'n

And to Eternity doe hold

Finis 
[p. $551 \mathrm{c}]$ The Recreations of my Solitude

$\mathrm{T}: \mathrm{F}$

[p. 552]

THE SOLITUDE

O how I lone these Solitudes

And places silent as the Night

Ther wher noe thronging multituds

Disturbe $w^{\text {th }}$ noyse ther sweet delight

O how myn eyes are pleas'd to see

Oakes that such spreadinge branches beare

$\mathrm{W}^{\mathrm{c}} \mathrm{ch}$ from old Time's netiuity

And thenuy of so many yeares

Are still greene beautifull \& faire

As att the world's first day they were

Naught but the highest twiggs of all

Wher Zephyrus doth wanton play

[p. 553 Doe yett presage ther future fall

Or shew a signe of ther decay

Times past Fawnes Satyrs Demy-Gods

Hither retird to seeke for Aide

When Heauen $w^{\text {th }}$ Earth was soe att odds

As Jupiter in rage had laide

Ore all a Dehnge these high woods

Preseru'd them from the sweling floods

Ther vnder a flowry Thorne alonge

Of springs delightfull plint the Cheife

Sadd I'hilomela's mournfull songe

Doth sweetly entertaine my yreefe

And to behold is noe less rare

|p. 5.5t These hanging Rocks \& Precepies

IV th to the wounds of sadd dispare

Are soe propitions to grine ealse

When soe oprest hy crinel fite

Death's souglit for att another gate 


\section{[LA SOLITUDE ${ }^{1}$}

A Alcidon.

Que j’ayme la solitude!

Que ces lieux sacrez à la nuit, Esloignez du monde et du bruit, Plaisent à mon inquietude!

Mon Dieu! que mes yeux sont contens

De voir ces bois, qui se trouverent

A la nativité du temps,

Et que tous les siecles reverent,

Estre encore aussi beaux et vers,

Qu'aux premiers jours de l'univers!

Un gay zephire les caresse

D'un mouvement doux et flatteur.

Rien que leur extresme hanteur

$\mathrm{Ne}$ fait remarquer leur vieillesse.

Jadis Pan et ses demy-dieux

$\mathrm{Y}$ vindrent chercher du refuge,

Quand Jupiter ouvrit les cieux

Pour nous envoyer le deluge,

Et, se sauvans sur leurs rameaux,

A peine virent-ils les eaux.

Que sur cette espine fleurie, Dont le printemps est amoureux, Philomèle, au chant langoureux, Entretient bien ma resverie!

Que je prens de plaisir à voir Ces monts pendans en precipices, Qui, pour les coups du desespoir, Sont aux malheureux si propices, Quand la cruauté de leur sort Les force à rechercher la mort! 
How pleasant are the Murmuring stream

In shady Vallyes runinge downe

Whose raginge torrents as itt seemes

Just measurs keepe in skpps \& bounds

Then glidinge vnder th' arbored banks

As windinge Serpents in the grass

The sportfull Naides playes ther pranks

[p. 555] V'pon the watry plaines of Glass

The christal Elements wherin

These watry Nimphes delight to swime

The quiet Marshe I loue to see

That bounded is $\mathrm{w}^{\text {th }}$ willowes round

With Sallow, Elme, \& Popler tree

Wch Iron yett hath giuen noe wound

The Nimphes that Come to take fresh Ayre

Here Rocks \& Spindles them prouide

Mongst Sedge \& Bulrush we may heare

The lepinge Froggs Se wher they hide

Themselues for feare when they espye

A Man or Beast approachinge nye

[p. 556] A hundred thousand Fowle her lye All voyd of feare makinge ther Nest

Noe treachrous Fowler here Comes nye

$W^{\text {th }}$ mortal gumnes to breake ther rest

Some ioying in the sunn's warme beames

Ther fethers buisily doe plume

Whilst others findinge Loue's hott flames

In waters allsoe can Consume

And in all pastimes Inocent

Are pleased in this Element

How pleasant is itt to behold

These ancient Ruinated Towers

\{p. 557] 'Gainst w wh $^{\text {ch }}$ the Giants did of old

$W^{\text {th }}$ Insolence imploye ther Powers

Now Sayters here ther Sabath keepe

And Sperits $w^{\text {ch }}$ our sence inspire

$W^{\text {th }}$ frightinge dreames whilst we doe sleepe

Noe here againe all dily retire

In thousand Chinkes \& dusty holes

1.yes rgly Batts \& Seritchinge Owles 
Que je trouve doux le ravage De ces fiers torrens vagabonds, Qui se precipitent par bonds Dans ce valon vert et sauvage! Puis, glissant sous les arbrisseaux, Ainsi que des serpens sur l'herbe, Se changent en plaisans ruisseaux,

Oì quelque Naïade superbe

Regne comme en son lict natal,

Dessus un throsne de christal!

Que j'aime ce marets paisible!

Il est tout bordé d'aliziers,

D'aulnes, de saules et d'oziers,

A qui le fer n'est point nuisible.

Les Nymphes, y cherchans le frais, S'y vienment fournir de quenouilles,

De pipeaux, de joncs et de glais;

Oir l'on voit sauter les grenouilles,

Oui de frayeur s'y vont cacher

Si tost qu'on veut sien approcher.

Là, cent mille oyseaux aquatiques

Vivent, sans craindre, en leur repos,

Le giboyeur fin et dispos,

Avec ses mortelles pratiques.

L'un, tout joyeux d'un si beau jour,

S'amuse à becqueter sa plume;

L'autre allentit le feu d'amour

Qui dans l'eau mesme se consume,

Et prennent tous innocemment

Leur plaisir en cet element.

Que j'ayme à voir la décadence

De ces vieux chasteaux ruinez,

Contre qui les ans mutinez

Ont deployè leur insolence!

Les sorciers y font leur sabat;

Les demons follets s'y retirent,

Qui d'un malicieux ébat

Trompent nos sens et nous martirent;

Là se nichent en mille troux

Les couleuvres et les hyboux. 
These Mortal Augurs of Mischance

Who funerall notes as Musick makes

The Goblins singe \& skipp \& dance

In valts ore spred $w^{\text {th }}$ Toads \& Snakes

Ther in a Cursed beame might see

[p. 558] The horred Skeliton of some poore louer

$W^{\text {eh }}$ for his Mistriss Cruelty

Hanged himselfe sence naught could moue her

Or $w^{\text {th }}$ a glance nott once to daine

To ease him of his mortal paine

The Marble Stones here strew'd about

Of Carracters leaue yett some signe

But now are almost eaten outt

By teeth of all deuouring time

The planks \& timber from aboue

Downe to the lowest Valts are fau'ne

Wher Toads \& Vipers 'mongst them moue

Leaninge theron ther deadly spawne

[p. 559] And Harths that once were vs'd fvr fyers

Now shaded are $w^{\text {th }}$ scratchinge Bryers

Yet lower an Arched-V'alt extends

Soe hiddious darke \& deepe doth sinke

That did the Sun therin desend

I thinke he scarce Could se a winke

slumber that from heany Cares

Wth drowsiness inchants our sence

sleepes here secure, as far from feares

Lul'd in the Armes of Negligence

And on her back in shuggish sort

Vpon the pauement lyes \& Snort

[1. 560] When from these Ruings I doe goe

$V_{p}$ an aspiringe Rock nott farre

Whose topp did seeme ast were to know

Wher mists \& stormes ingendred are

And then desending att my leasure

Downe patlus mate by the storming Wanes

I did behold $w^{\text {th }}$ ureater pleasure

How they did worke the hollow Canes

A worke soe Curious \& soe rare

As if that Neptuns (onnt were ther 
L'orfraye, avec ses cris funebres, Mortels augures des destins, Fait rire et dancer les lutins Dans ces lieux remplis de tenebres. Sous un chevron de bois mandit $\mathrm{Y}$ branle le squelette horrible D'un pauvre amant qui se pendit Pour une bergère insensible, Qui d'un seul regard de pitié Ne daigna voir son amitié.

Là se trouvent sur quelques marbres Des devises du temps passe; Icy l'âge a presque effacé Des chiffres taillez sur les arbres; Le plancher du lieu le plus haut Est tombé jusques dans la cave, Que la limace et le crapant Souillent de venin et de bave; Le lierre y croist au foyer, A l'ombrage d'un grand noyer.

Lá dessous s'estend une voûte Si sombre en un certain endroit, Que, quand Phebus y descendroit, Je pense qu'il n'y verroit goutte;

Le Sommeil aux pesans sourcis, Enchante d'un morne silence, $\mathrm{Y}$ dort, bien loing de tous soucis, Dans les bras de la Nonchalence, Laschement couché sur le dos Dessus des gerbes de pavos.

Tantost, sortant de ces ruines, Je monte au haut de ce rocher, Dont le sommet semble chercher En quel lieu se font les bruïnes; Puis je descends tout à loisir, Sous une falaise escarpée, D'ou je regarde avec plaisir L'onde qui l'a presque sappée Jusqu'au siege de Palemon, Fait d'esponges et de limon.

1 Fuirfax omits a stanza here. 
Tis a delightfull sight to see

Standinge on the mururinge shore

[p. 561] When Calmer Seas begin to bee

After the Stormes wch raginge roare

How the blew Trytons doe appeare

Ipon the rollinge Curled ITaues

Beatinge $w^{\text {th }}$ hiddious tumes the Ayre

IVth Crooked Trumpets Sea-men braues

Att whose shrill notes the winds doe seeme

$\mathrm{By}$ keepinge still to beare esteeme

Sometimes the Sea $w^{\text {th }}$ Tempests rore

Frettinge itt Can rise noe higher

Roulinge or'e the flinty shore

Throwes them vp againe retirés

[p. 562] Somtimes through itt's deuouringe Jawes

When Neptun's in an angry moode

Poore mariners finde his Cruel lawes

Made to his finy Subiects foode

But Diamonds Amber \& the Jett

To Neptune they doe Consecrate

Sometimes soe Cleare \& soe serene

Itt seemes ast were a looking glass

And to our Vewes presenting seemes

As heauens beneath the waters was

The Sun in it's soe clearely seene

That contemplatinge this bright sight

[p. 563] As't was a doubt whether itt had beene

Himselfe or image grate the light

Att first appearing to otir eyes

As if he had falne from the skyes

Thus Alcidon whose loue inioynes

To thinke for thee noe labor paine

Receaue these Rustick shepheards lines

That's from ther lininge obiects taline

Sence I seeke only desirt places

Wher all alone my thoughts doe use

Noe entertainment but what pleases

The genius of my hiural Muse

But nue thoughts more delighteth mee

Then sweet liemembrances of thee 
Que c'est une chose agreable D'estre sur le bord de la mer, Quand elle vient à se calmer Après quelque orage effroyable! Et que les chevelus Tritons, Hauts, sur les vagues seconées, Frapent les airs d'estranges tons Avec leurs trompes enrouées, Doat l'eclat rend respectueux Les vents les plus impetueux.

Tantost l'onde, brouillant l'arene, Murmure et fremit de courroux, Se roullant dessus les cailloux Qu'elle apporte et qu'elle r'entraine. Tantost, elle estale en ses bords, Que l'ire de Neptune outrage, Des gens noyez, des monstres morts, Des vaisseaux brisez du naufrage, Des diamans, de l'ambre gris, Et mille autres choses de pris.

Tantost, la plus claire du monde, Elle semble un miroir flottant, Et nous represente à l'instant Encore d'autres cieux sous l'onde. Le soleil s'y fait si bien voir, $Y$ comtemplant son beau visage, Qu'on est quelque temps à sçavoir Si c'est luy-mesme, on son image, Et d'abord il semble à nos yeux Qu'il s'est laissé tomber des cieux.

Bernières, pour qui je me vante De ne rien faire que de beau, Reçoy ce fantasque tableau Fait d'une peinture vivante. Je ne cherche que les deserts, Ou, resvant tout seul, je m'amuse A des discours assez diserts De mon genie avec la muse; Mais mon plus aymable entretien C'est le ressouvenir dı tien. 
[p. 564]

Of a Faire IVife

to Coregio

Thou thinkst Coregio thou hast gott

An exelent Beauty to thy lott

But yet remember this againe

For pleasure also thou'lt hane paine

No perfect rest can be to thee

When watchfull always thou must be

T'is hard \& difficult to keepe

That all the world desire \& seeke

Is her beauty much, Then know

Her pride's noe less $w^{\text {ch }}$ she doth show

$[p .565]$ Dost thou admire her th'more will shee

For thy esteeme disdainfull be

But is shee faire Consider this

If shee be chast, some doubt it is

As shee in hansonnes exceeds

Soe much of Modesty shee needs

Sheel alwayes be a Mistress there

Wher only thou Comand should beare

But wouldst thou hane me to define

This rare beauty that is thine

Thy Idoll as thou make's of itt

Much more of Hurt then grood thoule wett

[1.566] For th' Adoration by thee ginen

Gines thee a Hell insteade of Heanen

New hal its daly shee will axe

And if denyed then shee will vex

And thinke all's nothing in her passion

That's nott in the Mode \& fishion

As if her Body were assignid

To gine inquietud's to thy minde

Me thinke I see thee rauisht on her

Thou hlinde (as Idolizinge) I.ouer

Ma'as soone begett Ixion's brood

On Juno's Imatge in a cloude 
[p. 567] Why shouldst thou longer thus submit To her who to obay's more fitt Least when thy Reason once is lost Thy Liberty too itt will Cost And in the end butt as a slaue A soueraine for Companion haue To say noe worse of Beauty I Conclucte It is but an Ilustrious seruitude

$[$ p. 568]

$$
\text { Of Beauty }
$$

Beauty's a fraile \& brittle good Wch Sicknes Time \& Age doe blast The Rose \& Lilly in face thatt budd Hardly are keept \& seldome last What hath she then to boast on Saue

A fragil life \& timely graue

Beauty wher sweet Graces faile May be Compared vnto this

A goodly ship $\mathrm{w}^{\text {th }}$ out her saile

A spring her fragrant flower doe miss

[p. 569] A day want's Sun or Torch itts Light

A shrine want's Saint or Starless night

But how doth Nature seeme to smother

The Virtues of this louely Flower

Who is of wanton Lust the Mother

Of toyinge Vanity a Bowre

Enimy of Peace the Fount wher Pride doe swime Th' Incendeary of Strife of Passions Magazen

Noe Beauty Spots should ladyes weare

They but the Spots of beauty are

Who knowes nott this (saue foolish Sotts)

That Beauty aught to haue noe Spotts

Some note a Spot that Venus had

Admitt itt were in one soe badd

Yett should nott shee haue Spots vpon Her

That would be held a Maide of Honor 
All Creaturs else on Earth that are Whether they Peace affect or Warre Males ther Females ne're opress By the Lyon safe lyes the Lyoness

[p. 57.2] The Beares ther Nates noe harme procure IVth Wolfe the shee Woolfe liues secure

And of the Bull the Earth wch teeres The tender Heyfer has noe feares But men then these more brutish are Who wth ther wiues Contend \& jarre

\section{Of Enuy}

In Enuy's Face discerne I this Of Monsters shee most Monstrous is A hurtfull grance her eye doth dart A painfull paine lies att her hart [1. 573] Noe Good doe's Man enioy by likght Her enuious teeth doth nott bitte To Carracterize her yitt more fitt Of Erringe blindness shee the Pitt A Hell to Natures swetest Life Reuenges Spur the flame of Strife Her Actions yett bespeake her worse To Ciuill Peace a vexinge Curse Temptation's Sargent that's assign'd The sientinell of Restless minde More hurtfull to the soule by farr Then Vipers to the body are But in a word t'express this Euell T'is the Sin peculier to the Duill

Noe Passion's ronted deeper or extends Her hranches furcler or that more offends Then Coller doth of weth no sex or Age Cam boast a full exemption from itts rabe And when it's boundless fury growes It's high distemper Mathes sliowes 
Soe oft as Man is Angery oh tis sadd He's nott only weake but blinde \& Madd Error for Truth imbraces \& t'wer well If dearest freinds from enimys he Could tell A harmeless smile or from the eye a glance Though vndesign'd puts him into a trance

[p. 575] And when his fury wakes how oft tis seene Frendships most sacred bonds disolued haue beene Who doth nott then discerne in sundry fashions How Man afflicted is $w^{\text {th }}$ Angry passions More feirce then are some Brutes as may apeare They sometimes yeilds but he's in full Cariere As Mariners when $w^{\text {th }}$ amazement smitt The Pilots voyce in stormes regards nott itt Soe men in frenzy ther strange gesters are Wild as the beasts \& Irreguler The flaminge fire $w^{\text {ch }}$ Passions kindle flies In furious sparkes from his piercinge eyes His angry face by a reflux of blood That from his Hart assends becometh rude

[p. 576] His haire $w^{\text {th }}$ gastly horror stands vpright And euery word he speakes he seemes to bitt His hands \& feet in ther excentrick Motions Breath naught but threats $w^{\text {th }}$ rash \& bloody notions His Lookes soe terrible as doe portend A fatal Change vnto his nearest freind What must be then's distempred soule $w^{\text {th }}$ in soe vgly outward, but a sinke of Sin

\section{Of Virtue}

As wel tun'd Musick sweetly seize

The sences soe doth't Virtue please

The Virtuous, force the Vitious too

Th'admire in others what they should doe

Those best loue virtue \& her lawes

That most Contemnes men's vains aplaues

Vertue alone all Grace inhance

And she noe vse doth make of chance

Whose effects are transcent in th' euent

What proceeds from virtue's permenent 
Those things itt slights the IVorld doe hold Pretious as Fortumes Goods \& Gold

[p. 578] These hath ther wings \& flye away

When Man desireth most ther Stay

The virtious Soule prize most that some

Thinkes but from sheepesh nature Come

And nott from Grace the spring frö whence

Flowes Virtue Goodnes Inocence

Care thou for these sence they'le apeare

Nuch surer Goods then Riches are

Thy virtious acts goe wher thou will

For Companions thou shatt haue still

When Men shall faile \& freindship both

A better frende $w^{\text {th }}$ thee then goe'th

Enuy att death shal Cease in Foes

No Post-hume enel Malice knowes

[p. 579] In transendent hight shal vertue shine

Wher feet of Enuy Can not clime

Virtue alone doth death outliue

As't t'wer againe new life doth giue

IVhilst Goods of Fortune here haue ends

Virtue alone to heauen assends

[p. 582]

Nature \& Fortune

What thing is nature we may thus define God draws't through Beings in directst line

Wher as in Fortume soe miscal'd by some

More Crooked is \& in Nleanders rune

As Natur's rule by prouidence demine

soe fortune too in an obstrucer line

Then Fortune is not blinde as vaine men says

Tis they are blinde discerning not her wayes

[р. 58:3|

The Christian War-fire

The marke of note Gods children here doe beare

ls from the Workl's a different Carrecter

He to thine for portion here beneath

Doth Losses, shame is L'ouerty leepueath 
Yett happy those Aflictions wee account That to the State Eternal doe amount The worldly brood if we Caractrize Th' haue noe Aflictions liue in Paridize Ther Riches here as they desire angment Ther Honors too increase to ther Content But as a dreame these Honers vanish soone And an eternal woe shal take ther Roome As fatt of Lambes away they shall Consume Ther Honor vanish into smolie \& fume

[p. 584] T'indure sorrowes \& Iniuryes we must (As Scriptures tel) \& be to exile thrust Then tis a signe indeed heauen is our choyse When in our Tribulations wee reioyce T'is Gileads pretious Balme \& serues to binde The wounds \& blowes $w^{\text {ch }}$ here below we finde Yea happy choyse though thus the World vs treat Seing that in heauen our reward is great The Soulder of that name vnworthy is That trembles att the sight of enimyes Soe is the Christian $w^{\text {ch }}$ that title bear's If he att threats of aduerse destine fear's But $w^{\text {th }}$ a patient calmness lett's receaue What the Someraigne hand is pleas'd to gine [p. 585] The Midle Region or those parts aboue

Are least obscurd nor ther doe Tempests moue Soe should our soules be raysd boue Passions sphere Noe Stormes of Tongues Nor Cloudes of enuy feare In fronts of Batailes we our fortunes Sett The Ship at Sea $w^{\text {th }}$ stormy winds is bett The Pilot scapt from former gusts noe more Feare's ship-wrack now then what he did before The Soulder oft to frequent perills knowne Neglect's the danger that's soe Comon growne And soe should we when our Aflictions growe $W^{\text {th }}$ lenghtned Patience learne to beare them too This Life's a war-fare if sometimes begun To parly $w^{\text {th }}$ our sorrowes t'is soone done And in th' end when hopes begin to Cease

[1. 586] Proues but a Cessation noe Continu'd Peace

Whilst through cleare skyes the Sun triumphant rides Vpon a sudden cloudes his splendor hides 
Doth health \& Pleasture spur our sences on soon sickness Comes and all delights are gone such is the State of vs rncertaine men

To know in calmes to guide our V'essels then Is not enough, but t'is when Tempests rise To steare a Course both Patient, Stout, \& Wise Did our misfortunes soe deuide our share As some shee would Aflict \& others spare We might Complaine of her inconstant fitts Bullets as soon th' Captaine as soulder hitts The Feauer to the Great a deafe eare hath

[p. 587] As to the meanest both subuerts by death Soe may the Justice of Impartial fate For Comfort serue vs in our greatest Strait Why doe we enuy then aspiringe Men Wth Stormes the Vallyes are less troubled then The lofty Hills \& humble shrubbs belowe Less dangrer's in then Oakes that highest growe ${ }^{1}$ See we not how the straitest Popler tree And spredinge Elme as they vingratfull be For nurishment) to barreness incline Whilst prostrate on the ground the Crocked vine Abundance yeilds or hane we nott seene From highest plenty men in wants haue beene How many Kings falne from ther Regall seate Haue Crack their Crownes ther Royal Septers breake

[p. 588] Our Wittnesses by cloudes we all may bringe To shew that splendid honours a vaine thinge Should they be ta'ne from r's resolue thus much Ther loss should not be wreat ther fading's such should we aflict ourselues when loss appear's Our Teares would somer want then Canse for teares All you wth heauenly Marks of God indued Arme to the firght shew Virtue Fortitude As Rocks 'gainst w' the raging billowes rore Keepe firme ther station on the threatned shore Soe let our Sioules be firme \& (onstiut still Against the threats this World doth make of Ill Or as a Diamon monest the dust doth dart The beauty more in itt's resplendent sparke 
[p. 589] In midst of troubles soe lett vs demeane As Countinances be pleasant Soules serene Remember t'is from high Aflictions fall From Prouidence deuine that gouern's all Who when he please in turning of an eye Turn's Wrath to Mercy Sorrows into Joy $T$ is he who made the firtile Earth produce Her anual fruit most meet for humaine vse He both the Rose \& Violets did Cloth T'is he beauty \& th'oders gaue to both 'Twas his Almighty' power that did make fall Att Israels seige the Jereconian Wall That on's Enimyes ruing he might raise Trophy on Trophy to inrich his Prayse

[p. 590] Shal we then those his wonders now less prize Or thinke his Power abat's, or hee less wise No, hee's as able still Nor shall His want Victory on Standards Glory on ther front

[1. 590] Life \& Death Compared together Such vulgar thoughts the World doe fill To thinke Life good Death only ill Then life ill lined noe enell's worse Death (dieing well) remoues the Curse And tis for certaine truth men tell He ne're dies ill that lineth well Ill lines doe but ther Ills increase [p. 591] But dieng well makes Euells Cease Badd men haite death but not soe much That itt is Ill, as They are such Moral Men teache vs in their bookes That we should dispise death's grime lookes $T$ 'is Comon sence $w^{\text {ch }}$ doth inspire Ther feares of that Good men desire Nor Can we truly death define By makinge odious what's sublime Consider't in th' effects \& soe itt will Plead much for death be't Good or Ill Say itt be Ill yett here's the Good To greater Ills it gines a period In life what one grood thinge is ther 
[p. 592] To keepe our Passions Reguler The many Ills each day is done Makes Death less fear'd but once to come But rather thanke Death that's the Cause Our Ills are not Imortal Lawes

[p. 592] Vpon a Fontaine

Seest thou how these waters flowe How soone againe away itt glides Soe worldly Glory's but a showe That neuer long $w^{\text {th }}$ vs abides ${ }^{1}$

[p. 593] I'pon the New-built House att Apleton

Thinke not ô Man that dwells herein This House's a Stay but as an Inne $\mathrm{W}^{\mathrm{ch}}$ for Conuenience fittly stands In way to one nott made $w^{\text {th }}$ hands But if a time here thou take Rest Yett thinke Eternity's the Best

In Rosy morine I saw Aurora red But when the Sun his beames had fully spred She vanisht I saw a Frost then a Dew T'wixt time soe short as scarce a time I knew This stranger seemd when in more raised thonght 1 saw Death Come How soone a life he'ad Caught Wher in the turninge of an eye he'ad done Farre Speedier execution then the Sun 
O what affront was itt to Nature And sadder Influence of the Skyes That in a moment clos'd the Eyes Of such a machless Creature

But askinge what might be the Reason That Cremel Fate soe out of season Had Caried her from vs soe farre This Answer was to me returnd Least that the Earth should bee burnd By th' scorching beames of that bright starr

[1. 596] The Lady Caryes Elogy on my deare Wife

O Fatal fall might not those heapes suffice This Suñer Captiu'd but thou must surprize The best of Nobels this soe great good Lady A Vere A Fairfax Honours-Honour, Shee Did grace her Birth Sex Relate \& Degree \& Shee a Non-parell for Piety Vers't in the Theory of Godliness The $w^{\text {ch }}$ she did in Conference express Its Practick part her life to life did shew Each way but most excellinge in all vew Was Faith Submission vnweared pleasantnes

[1.597] With rniuersal weaknes, Paine Sickness Many longe lasting Great few euer sence Soe followed Job in suffringe Patience But she is now most gloriously exalted Wher sin \& sorrow neuer entred To Mount Zion heauenly Jerusalem The City of God to Sperits of Just men To Church of the first borne to Angels blest To God to Jesus this Compleats the rest Her Faith saw this w made her smile att death And w $^{\text {th }}$ much Joy surrendred vp her breath Her Body deare her All thats out of Heauen To Billbrough cluurch as a riche Treasure's giuen Bilbrough church-yeard daine me a little roome That after death my graue waite on her Tombe. 
[p. 598]

To the Lady Cary

Ypon her Verses on my deare Wife

Madam

Could I a Tribute of my thanks express

As you hane done in lone \& purer Verse

On my best selfe then I might Justly raise

Your Elogy t'Encomiums of your Prayse

And soe forgett the Subiect that did mone

Me to a thankfulnes as't did you to loue

Ô t'were to great a Crime but pray' allow

Wher I fall short but you haue reached to

Makinge that Good wisest of Kings hath said

Th' Liuing's not soe I'reyse-worthy then the dead

I thinke the Reason's this itts grounded on

Cause Mercys are not prizd till they are gone

[p. 599] O had not hopes surpast my grosser sence My loss Could not haue had a recompence Yett such an Influence hath your happy straine

To bring my buried Joy to life againe

Vertue Goodnes Loue things Imortalize

The better part when as the other dies

True, Soules in Bodyes haue ther being here

But Loues in Soules haue ther ther proper Sphere

Then is true loue Compos'd of Nobler fyers

Then to extinguish when the Life expires

Butt to Conclude Madam me think you 'spire

In humblest Thoughts to raise your Trophys higher

Then Her's you would attend in gelid lloukl

IVch for her Friend the lodging seemes too Could

[p. 600] But were itt soe itt my grood happ might bee

To lye next Her, To you our Quire is free

[p. 600]

On the Fatal day

Jan: 301648

Oh lett that Day from time be llotted quitt

And lett belecfe of $t$ in next Age be waned

In deepest silence th Act Concealed might

soe that the King-(lums. Credit might be saned 
But if the Power deuine permited this

His Will's the Law \& ours must acquiesse

Curæ loquuntur leues

Ingentes stupent

[p. 601]

Of Inpartial Fate

Here we all the Same Danger run

By the like Destin's we are ledd

Same Misfortune to the Shepeard Come

May attack as well the Crowned head

Our dayes are Spun vpon that wheele

The meanest Subiect \& greatest Kinge

To like end th' Fatal sisters bringe

The thread when Cutt both same Sisers feele

[f. 604]

A Carracter of the Romish

Church by Francisco Petrarca

Laura Can : 106

Fiamma dal ciel su tue treccie pioua

Heauens dire flame sits on thy Curled tresses

O wrech, from scrip \& wallet who's become

Both riche \& great through those $w^{\text {ch }}$ thon oppresses

Soe much reioyces thou when euells Come

A nest of Treasons wher mischeifes bredd

Ther hacht in the o're the World is spred

Wine Bed good Belly chere \& pleasant dayes

To All, thy whoredoms to the vttmost shews

[p. 605] Thy seruants younge \& old the wanton playes

This fire $w^{\text {th }}$ bellowes Bel-ze-bul blowes

Such is thy life thou wicked Epicure

As to the Heauens thy stinch is gone vp sure

Fountaine of Greefe \& woe wraths harbor too

Temple of Heresy Pitt of Errors deepe

In elter times we held thee Rome but now

Babel the peruerse for $\mathrm{w}^{\mathrm{ch}}$ wee weepe

A shopp of Cousnage prison of Crueltyes

Wher ills mentaind \& wher Goodnes dyes 
When founded first wast humble Poore \& Chast Thy hornes against thy Founders now thou lifts

[p. 606] O shameles Strumpet wher's thy trust now plast Is't in th' Adultryes ill gott Goods or Shiffts Then vnto All great wonder itt will bee If Christ in th' End powre nott his wrath on thee ${ }^{1}$

[Fiamma dal ciel su le tue trecce piova, Malvagia, che dal fiume e dalle ghiande, Per l'altru' impoverir se' ricca e grande; Poichè di mal oprar tanto ti giova:

Nido di tradimenti, in cui si cova

Quanto mal per lo mondo oggi si spande;

Di vin serva, di letti e di vivande, In cui lussuria fa l'ultima prova.

Per le camere tue fanciulle e vecchi

Tranmo trescando, e Belzebub in mezzo

Co' mantici e col foco e con gli specchi.

Già non fosti nudrita in piume al rezzo,

Ma nuda al vento, e scalza fra li stecchi:

Or vivi si, ch'a Dio ne venga il lezzo.

Fontana di dolore, albergo d'ira,

Scola d'errori, e tempio d'eresia;

Gia Roma, or Babilonia falsa e ria,

Per cui tanto si piagne e si sospira.

O fucina d'inganni, o prigion dira,

Ore '1 ben more, e "l mal si nutre e cria:

Di vivi Inferno; un gran miracol fia,

Se Cristo teco alfine non s'adira.

Fondata in casta ed $11 \mathrm{mil}$ povertate,

Contra tıoi fonclatori alzi le corna,

Putta sfacciata: e dov' hai posto spene?

Negli adulterj tuoi, nelle malnate

Ricchezze tante? Or Constantin non torna;

Ma tolga il mondo triste che 'l sostenc." ]

1 Siee page 245.

2 These sonnets ale not in the MS. 
[p. 612]

Tpon the Horse $w^{\text {ch }}$ his Matie

Rode vpon att his Coronation 1660

Hence then Dispaire my hopes why should itt bury Sence this braue Steed Bredd first was in my Query Now thus aduanc't w $^{\text {th }}$ highest honors loden Whilst his that bredd him on by most Mens troden But t'is noe matter Seing tho' hast gott th' Aduance Then please the Royal Rider $w^{\text {th }}$ thy Prance Soe may thy Fame much rayse thy Prayses higher Then Chessnut that begott the or Brid-la-dore his Sire

\section{Bridla-dore (Anglicè)}

Golden Bridle

[p. 613]

$$
\text { Vulgar Proverbs }
$$

None to another freind can be

That to himselfe's an enimy

[p. 614] Of sence \& Money \& of Faith

Where's the Man that too much hath

Betwixt the Bridle \& the Spur

Reason often lodgeth her

In th' house of Foes prepose this End

To gett some Woman for thy freind

[1. 615] The Hope of Gaine-Abateth paine

Wouldst thou have all thy troubles cease

Then see $\&$ heare $\&$ hold thy peace

Lait (doe we say) repents the Ratt

When by the Neck has hold the Catt

His thoughts are good \& ever best

That carryes Death w $^{\text {thin }}$ his brest

[p, 617] A fatt Earth makes a Horse to labour

But A good Lawyer is an ill Neighbour

Nake Night of Night \& Day of Day

Soe $w^{\text {th }}$ less sorrow live you may

[1. 618] Pardon to Men that evel be

Unto the God's an injury 
When Pride on horseback getteth upp

Loss \& shame sitts on the Croup

[p. 620] He that would live in healthfulnes

Must dine $w^{\text {th }}$ little $\&$ supp $w^{\text {th }}$ less

[p. 621] As the evening doth the day comend

So life is Praysed by the end

[p. 622] Virtue shewes the greater grace

shining from a bautious face

[p. 624] Att a rounde Table noe Strife is

Who shal be nearest a good Dish

Dry March Wett Aprel May that's both

Brings plenty wher ther is noe sloth

[p. 625] In a fresh gale

Extend thy Saile

[p. 626] We may be sure still inocence

Beares in itselfe its owne defence

[p. 627] To read \& yitt to have leam'd nought

Is like the chase wher nothing's caught

[1. 628] Tis good we should the tongue connand

Speake litle \& more understand

For if from us our words once fall

It is too laite them to recall

Humaine Praise-Is a vaine blaze

[p. 631] Sett on al Seat a Foole e're longe

Hele waterg his Legueses or sing a songer

[p. 633] Nature made nothing so subline

Butt Virtue to the topp will clime

When a whit frost on earth doth lie

Tis a presibge then rame is nic

|p. 63i) ()n a womans first (inmsel rest

sieldome the second is the lest

Bread Butter \& grod cheese

A shield irainst death he al these

Trans. roxn. Aram. Vol. XIV.

19

itน. 1904 . 
Pardon give to every one

But to thyselfe alow none.

[p. 637] When Italy is $w^{\text {th }}$ out Fish

When France w $w^{\text {th }}$ out Treason is

In England longe noe war we see

Then $w^{\text {th }}$ out Earth the World shall bee.

[p. 638] My contry is in all lands wher

I goe \& meet $w^{\text {th }}$ true friends ther. 
$[$ p. 641]

The teares of France for the deplorable deatl of Henry 4 surnamed the Great

Al) is itt then Great Henry soe fam'd For taming men himselfe by death is tam'd What eye his glory saw now his sad doome But must desolue in Teares sigh out his soule soe small a shred of Earth should him intombe Whos acts deseru'd pocession of the whole $\mathrm{O}$ t'is but fitt for joyes we henceforth mourne Our songes \& mirth into sad plaints we turne Instead of this great $\mathrm{King}$ greefe may raigne here So that in sorrow plung'd our fainting breath May send our endless sighs to thighst sphere Whilst hopless teares distill vpon the earth

[1. 642] Yis itt is fitt what else can we returne Butt teares as offrings to his sacred vrne $W^{\text {th }}$ them bis sable Narble tombe bedew No no such armes too weake sence itt apeares For vis he of his blood too careless grew Haue we naught else for him butt a few teares

O could our eyes to fontains we distill T" Would nott aloaite the least part of our ill We oft shed teases for simple wrongs oft werpe Too Comon oft for thines of lesser prise Then lett vs die att this great Monarchs feet His Tombe th' Alter, our selues, the sacritice

But who can die if sinters Fate denies A closure to our half death trickling eyes Hating shut ve those of this warrlike Prince Atropos so proud's of her ruyal pray

Her Cypriss into laurels will turne, sence Of this great Victor she hath grott the day

[p. 643] Bunt sence we are ordain'd to sigh \& line And after this ther faitall stroke then wiue Line then complatinime this sald shock of fate Wher happy days are gone, no by appeares Then mourne of sigh till death our greefe alsate And shew whilst lining, tifi shal wast in teates 
[1 (2uoi? faut-il que Henri, ce redoute monarque, Ce dompteur des humains, soit dompté par la Parque? Que l'oil qui vit sa gloire ores voye sa fin? Que le nostre pour lui incessamment dégoutte? Et que si peu de terre enferme dans son sein Celui qui méritoit de la posséder tonte?

Quoi? faut-il qu'à jamais nos joies soyent esteintes? Que nos chants et nos ris soyent convertis en plaintes? Qu'au lieu de nostre roi le deuil règne en ces lieux? Que la douleur nous poigne et le regret nous serre? Que sans fin nos sousoirs montent dedans les cieux? Que sans espoir nos pleurs descendent sur la terre?

Il le faut, on le doit. Et que pouvons-nous rendre Que des pleurs assidus, a cette auguste cendre? Arrousons à jamais son marbre triste blanc. Non, non, plustost quittons ces inutiles armes! Mais puisqu'il fut pour nous prodigue de son sang, Serions-nous bien pour lui avares de nos larmes?

Quand bien nos yeux seroyent convertis en fontaines, Its ne sauroyent noyer la moindre de nos peines. On espanche des pleurs pour un simple meschef. Un devoir trop commun bien souvent peu s'estime. Il faut doncques mourir aux pieds de nostre chef. Son tombeau soit l'autel et nos corps la victime

Mais qui pourroit mourir? Les Parques filandieres Desdaignent de toucher a nos moites paupières, Ayans fermé les yeux du prince des guerriers. Atropos de sa proye est par trop glorieuse; Elle peut bien changer ses cypres en lauriers, Puisque de ce vainqueur elle est victorieuse.

Puisquil nous faut encor et souspirer et vivre, Puisque la I'arque fuit ceux qui la veulent suivre, Vivons donc en plaignant nostre rigoureux sort, Nostre bonheur perdu, nostre joye ravie; Lamentons, souspirons, et jusques à la mort Tesmoignons qu'en vivant nous pleurons nostre vie. 
Bewaile bewaile this our great Monarchs fall Of Judgment perfait humour pleasing all His equal none a Hart $w^{\text {th }}$ out all feare Perfection such t'would but fall short in prayse Enough to' aue serued a WVorld to' aue admird here Had nott his equal Justice bound his wayes Lament lament this sage \& Prudent King Thatt hight of Bonty, rigelence in him Thatt hart wch could be mou'd not onercome Virtues here rarely found though we inquire Parts I could sooner much admire then sume Sence this Achilis a Homer would require

[1. 614] We cañott count the splendours of his Glorys Nor number yitt his signal victorys O no for such a subiect were too great We aught to prayse what yitt we camnot write And hold our peace or to good purpose speake He nothing saith doth not to th' full recite

His famous acts once raisd our dromping heads His Laurels from the temples was our shades End of his Combats ended feares wee're in Him only pris'd dispis'd all other Powers More gloring to be subiect to this King Then if we'ad luad some other Kings for ours

But now this Glory's clouded $w^{\text {th }}$ a staine And now our joy \& Mirth ther leaue hath taine The Lillys faide as we att this sad Fate

Downe to the growne ther dromping heads doe bowe seeming as humble as Compassionate

To crowne his tombe or else him homage doe

$$
\text { [p]. } 6.15,6+6 \text { are blank }
$$


Plaimnons, pleurons sans fin cet esprit admirable, Ce jugement parfait, cet' humeur agréable, Cet hercule sans pair aussi bien que sans peur, Tiant de perfections (qu'en loüant on souspire. ( )ui pouroyent asservir le monde à sa valeur, Si sa rare équité nenst borné son Empire.

Regrettons, souspirons cette sage prudence, Cette extrème bonte, cette rare vaillance, Ce cour qui se pouroit fleschir et non dompter. Vertus de qui la perte est a nous tant amère Et que je puis plustost admirer que chanter, Puisqu' a ce grand Achille il faudroit un Homere.

Pourroit-on bien conter le nombre de ses gloires? Pourroit-on bien nombrer ses insignes victoires? Non, d'un si grand discours le dessein est trop haut. On doit louër sans fin ce qu'on ne peut escrire, Il faut humble se taire ou parler comme il faut, Et celui ne dit rien qui ne peut assez dire.

Jadis pour ses beaux faits nous eslevions nos testes, L'ombre de ses lauriers nous gardoit des tempestes, La fin de ses combats finissoit nostre effroi.

Nous nous prisions tous seuls, nous mesprisions les autres, Estant plus glorieux d'estre subjects dn roi Que si les autres rois eussent esté les nostres.

Maintenant nostre gloire est à jamais ternic, Maintenant nostre joye est pour jamais fuie; Les lys sont atterez et nous avecques eux. Dafnc baisse, chétifve, en terre son visage, Et semble par ce greste, humble autant que piteux, Ou couromner sa tombe ou bien lui faire hommagre.| 

University of California

SOUTHERN REGIONAL LIBRARY FACILITY

405 Hilgard Avenue, Los Angeles, CA 90024-1388

Return this material to the library

from which it was borrowed.

9. 14001998

valy $50 \mathrm{~cm}$ 


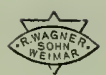

Univer Sou

Lil 